\title{
Errata
}

Diabetologia (1996) 39: 369

\section{The effect of cholesterol-lowering therapy on the progression of diabetic nephropathy is unproved (Letter to the editor by R. Bender)}

\section{Response from K.S. L. Lam and I. J. Lauder}

Drs. Lam and Lauder would like to correct the final two paragraphs and Table 1 of their response.

\section{Cholesterol lowering therapy reduces the rise in serum creatinine and urinary protein in NIDDM patients with nephropathy}

Between group comparisons of the incremental changes in serum creatinine and 24 -h urine protein excretion (Table 1) showed that the greater mean increments in the placebo group were not statistically significant at either 1 -year or 2 -year. The

Corresponding author: Dr. K.S.L.Lam, Department of Medicine, The University of Hong Kong, Pockfulham Road, Hong Kong differences in mean decrements in GFR were also not statistically significant.

A multicentre study involving a much larger number of patients will be required to demonstrate conclusively whether cholesterol lowering therapy does reduce the rate of progression of diabetic nephropathy.

Yours sincerely,

K. S. L. Lam, I. J. Lauder

Table 1. Effect of lovastatin on changes in serum creatinine, 24-h urinary protein and glomerular filtration rate

\begin{tabular}{lllllll}
\hline & $\begin{array}{l}\text { Serum creatinine } \\
(\mu \mathrm{mol} / \mathrm{l})\end{array}$ & \multicolumn{2}{l}{$\begin{array}{l}\text { 24-h urine protein } \\
(\mathrm{g})\end{array}$} & & & \multicolumn{2}{l}{$\begin{array}{l}\text { Glomerular } \\
\text { filtration rate } \\
\left(\mathrm{ml}^{-1} \mathrm{~min}^{-1} \cdot 1.73 \mathrm{~m}^{-2}\right)\end{array}$} \\
\hline & 1-year & 2-year & 1-year & 2-year & 1-year & 2-year \\
\hline Lovastatin $(n=16)$ & $2(-2,6)$ & $7(2,11)^{\mathrm{b}}$ & $0.005(-0.268,0.278)$ & $0.409(-0.008,0.826)^{\mathrm{a}}$ & $-2.95(-12.71,6.80)$ & $-2.03(-17.73,13.67)$ \\
Placebo $(n=18)$ & $6(1,11)^{\mathrm{b}}$ & $15(4,26)^{\mathrm{b}}$ & $0.291(-0.266,0.848)$ & $0.791(-0.060,1.641)^{\mathrm{a}}$ & $-2.76(-10.63,5.11)$ & $-10.85(-19.83,-1.87)^{\mathrm{b}}$ \\
$\begin{array}{l}P \text {-value } \\
\text { (2-sample } t \text {-test) }\end{array}$ & 0.203 & 0.170 & 0.356 & 0.402 & 0.974 & 0.287 \\
\hline
\end{tabular}

Mean (95\% confidence intervals); ${ }^{\mathrm{a}} p<0.1 ;{ }^{\mathrm{b}} p<0.025,1$-sample $t$-test

\section{Diabetologia (1996) 39: 649-657}

\section{Islet amyloid polypeptide (amylin) and insulin are differentially expressed in chronic diabetes induced by streptozotocin in rats}

\section{H.Mulder ${ }^{1}$ B. Ahrén ${ }^{2}$, F. Sundler}

${ }^{1}$ Department of Physiology and Neuroscience, Section for Neuroendocrine Cell Biology, University of Lund, Lund, Sweden

${ }^{2}$ Department of Medicine, Malmö University Hospital, University of Lund, Lund, Sweden

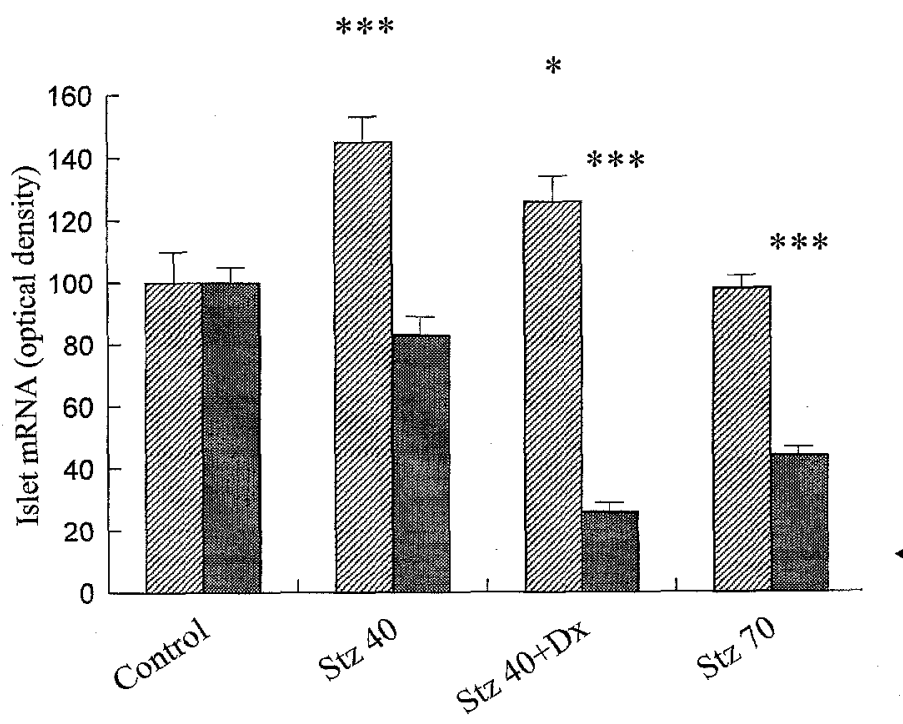

The legend to Figure 2 was inadvertently truncated. It is therefore reprinted here in the correct form
Fig. 2. Quantitative in situ hybridization as in Figure 1. IAPP

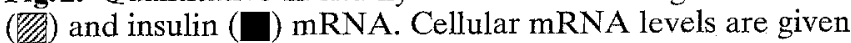
as optical density (mean \pm SEM) and expressed as percentage of control. Statistical measures as in Table $1 ; * p<0.005$; $* * * p<0.001$ vs control 